\title{
An Analysis of the Socio-Demographic Differences in Ecuadorian Economically Active Population between Genders
}

\author{
Gabriela Guevara-Segarra ${ }^{1}$, Saul Ortiz-Santacruz ${ }^{1} \&$ Efstathios Stefos ${ }^{2}$ \\ ${ }^{1}$ Business Administration Faculty, Universidad Politécnica Salesiana, Cuenca, Ecuador \\ ${ }^{2}$ Universidad Nacional de Educación UNAE, Azogues, Ecuador \\ Correspondence: Efstathios Stefos, Universidad Nacional de Educación UNAE, Azogues, Cañar, Parroquia \\ Javier Loyola (sector Chuquipata), Ecuador. Tel: 593-7-370-1200. E-mail: stefos.efstathios@unae.edu.ec
}

Received: June 9, 2017

Accepted: June 21, 2017

Online Published: June 27, 2017

doi:10.5539/mas.v11n8p7

URL: https://doi.org/10.5539/mas.v11n8p7

\begin{abstract}
Gender equity and development are common issues worldwide. International Organizations through their specialized programs and the states through their public policies have made high efforts to accomplish these goals raised internationally and locally. However, it is necessary to know the perception of the population about the achievement of these goals, and to influence the economic agents who are responsible of decision making. The present qualitative research work determines the social-demographic profile of the Ecuadorian economically active population and identifies the main characteristics by gender: racial group, activity and inactivity conditions, education, employment, poverty, and job satisfaction. The obtained results show the differences in variables related to activity and inactivity conditions, use of technology, education, and employment. The results pretend to be a useful source of information in the creation of public policies focused on poverty reduction and gender equity.
\end{abstract}

Keywords: development, education, employment, gender equity, gender parity, women

\section{Introduction}

Eradicating poverty, promoting universal education, gender equity, women's empowerment and equitable development are some of the United Nations Millennium Development Goals of 2000. In Ecuador, these objectives have been developed under the National Plan for Well-being (Senplades et al, 2014; Naciones Unidas, 2000). According to its executors, it has achieved remarkable results in the majority of its objectives and goals. Therefore, in order to determine the perception of the Ecuadorian population about these kind of issues, the objective of the present research work is to determine the demographic, financial, educational and social profile of men and women between 15 and 64 years old and remark the common characteristics and main differences between these two groups and relate these results to the development objectives planned by the government. The Employment, Underemployment, and Unemployment Survey (ENEMDU, 2015) has been taken as a reference in the study. It is important to mention that it uses standardized variables of International Labor Organization, making the results comparable internationally. The analyzed variables are: gender, age, marital status, language, racial group, place of birth, place of residence, natural region, educational attainment, activity and inactivity condition, activity branch, job satisfaction, training, technology use and access, income poverty and extreme income poverty (Organización Mundial del Comercio, 1998). This qualitative research used bidirectional contingency tables to identify the differences between men and women. The obtained results will be useful to contrast the official data with people's perceptions. It is expected that it influences the design of new economic and social public policies focused on reducing gender parity mainly in paid and unpaid employment, technological access and usage, training and other interesting information obtained from this research.

\section{Gender Equity and Development}

The United Nations Millennium Development Goals and the Sustainable Development Objectives agenda highlight the need of promoting gender equity and women autonomy (Naciones Unidas, 2017). The achieved results which are recognized as the most successful movement against poverty according to this organization, show that gender parity persists and that the advancement of this process has been dissimilar (Naciones Unidas, 2015). The main objective of Millennium Goals is social development, concept related to the research and achievement of higher living standards based on social investment generating a progressive social change and 
well-being, participation, and the relationship between the human action and the related policies (Midgley, 2014). This concept also has other determinant and related factors such as: investment, well-being and focused policies related to social capital, employment, education, and economy, among others that have an impact on the intended equitable development. Therefore, a brief analysis of these contextual factors of development to be followed by a segmentation by gender is necessary.

\section{Economy}

The economic variations are one of the most important effects generated in our environment mainly in terms of employment and health (Bambra, 2010). Although employment is an effective mean of income generation with a direct implication on the standard of living of people, and the main source of incomes in the western families, its importance has become a priority to the world since 1995 when it has become part of the UN Millennium Goals and International Labor Organization.

\section{Employment}

According to Escribà Agüir and Jaime Fons Martinez, labor conditions, organization and environment affect mainly to vulnerable groups such as women (Escribà Agüir \& Fons Martinez, 2014). It is know that it is also influenced by labor conditions. Jobs related to force and hand labor promote gender parity in labor and the difference between salaries (Castaño et al., 1999). However, ICTs are means to reduce these differences by improving the labor opportunities for women (OECD, 2007) requiring a particular education level and specific skills that are not related to gender such as: teamwork and knowledge (Carnoy, 2002). Employment, incomes, and development are also influenced by education, training, and according to Suárez Lantaron (2013) it is necessary to maintain the employment as a mean of social development based on abilities, skills and attributes that promote individuals (Suárez Lantaron, 2014). A similar approach is presented by Rentería \& Malvezzi when he suggests that employability means "the provision and maintenance of people in the labor market taking notice of their capabilities, productivity and performance" (Rentería Pérez \& Malvezzi, 2008) Summing this up, education influences people's capabilities and attitudes. Training and personal predisposition to learn will be key factors to achieve higher levels of employability (Formichella \& London, 2012).

However, it is also mentioned that an adequate education is not a guarantee or access to employment. There are some contextual factors that support this achievement. The Economic Commission for Latin America and the Caribbean (CEPAL) suggests that economic growth should be accompanied by adequate policies to reduce unemployment and social inequity (CEPAL, 2013).

\section{Maternity}

It is considered a natural factor that influences gender inequity. It has been considered a cause in the persistence of wage gap between men and women. Currently, women between 20 and 30 years old tend to quit their jobs to raise their children, and when they grow up, women come back to labor market. However, when they return to work, they find a lapse between their professional profile and their skills, and it is a long-term consequence the fact that they were not working. It is an important lapse between them and their male and single childless female competitors (Tito, 2016).

Vázquez Parra, Arredondo Trapero, \& de la Garza (2016) suggest that there are some socio-economic and cultural factors that limit the competitive development of a woman being one of them, the procreation (Vásquez Parra et al, 2016). Even research works done by developed countries state that gender inequity can be perceived in the labor market and this parity can be attributed to different impacts of paternity in women and men. Certain authors (Altonji \& Blank, 1999), (Blau \& Lawrence, 2000), y (Bertrand, 2010) including (Kleven \& Landais, 2017) advocate that women's incomes are more penalized than men's and that is attributed to maternity (Kleven \& Landais, 2017).

In this sense and in line with the Gender Disparity Report 2016, governments are called upon to create macro public policies to improve women's access to education and their economic participation. The gap between men and women in general has narrowed. It is said that the health gap has been exceeded in most countries over $80 \%$. However, the education gap and the economic participation of women remains important. This means that women continue to have more difficulties in accessing education and that they continue to receive less income or economic compensation than men in the labor fields. The gender disparity in Latin America and the Caribbean is 30\% on average and of the 25 countries considered within this region, Ecuador is among the countries with the lowest gender disparity, this ranks Ecuador in the 9th position, which is encouraging. However, the same report recognizes that, despite Ecuador's efforts to reduce gender disparity, the country has advanced in all criteria except in the category of professionals and technical workers. 
Several recent studies evidence the relationship between economic performance and gender parity. Therefore, reducing gender parity is important as it will have a positive effect on a country's economic growth. There are critical dimensions in which work is required such as the economic participation, education, health and politics. One of the advantages of reducing the gender disparity in economic participation might be, for example, an increase in the labor force and greater profit sharing. However, the integration of women into the formal economy is not the sole responsibility of the government, but of the private sector, which must be concerned with the internal structure and composition of workers and commit themselves to incorporate women in all organizations levels (WEF, 2016).

In Ecuador, which is currently ranked 40th in the world ranking on the gender gap in 2016 published by the World Economic Forum, 2016 and according to Millennium Goals Report Ecuador 2014, it is stated that 20 out of 21 targets were met and developed according to the National Plan of Well-Being in the objectives 2, 3, and 4 respectively including: gender inequalities in education and employment (Senplades et al, 2014). Despite the great advances in social development in Ecuador, a gap still exist according to the ethnic self-identification for example, the indigenous community shows lower percentages of development in education, mortality rate, satisfaction with the employment activity status, and so on (Castellano et al, 2017) Also, there is a relationship between the level of instruction and suicide. (Sarmiento et al, 2016)

Based on what has been referenced, by means of a qualitative analysis of the data compiled by the ENEMDU 2015 survey (INEC, 2015); a national employment, unemployment and underemployment survey carried out by the Ecuadorian Institute of Statistics and Censuses (INEC), several important aspects are intended to be determined. Those are the demographic, economic, educational and social profile of men and women between 15 and 64 years of age in order to observe the existing characteristics and differences between these two groups to relate them to the development objectives planned by the state. The variables analyzed are: gender, age, marital status, language, racial group, place of birth, place of residence, natural region, level of education, activity status and inactivity, branch of activity, job satisfaction, scientific update, access and use of technology, poverty based on low income and extreme poverty. The results of this study will be useful to contrast official data with perception, which is expected to influence the design of new public social and economic policies aimed to reduce inequality between men and women, mainly in labor matters, unpaid employment, and use of technology, training and other interesting data obtained from this analysis.

\section{Method}

The study uses as a reference statistical information from the 2015 National Survey of Employment, Unemployment and Underemployment (INEC, 2015). Given the objective of the present study, a descriptive analysis is done, with the former showing the frequency and percentages of the variables under investigation: gender, age, language, racial group, civil status, place of birth and residence, natural region, level of instruction, condition of activity and inactivity, branch of activity, job satisfaction, training, access and usage of technology, income poverty, and extreme poverty. The statistical analysis shows the frequency and percentages of the variables used in the investigation. We used contingency tables in order to explore the relationship between the variables under investigation and gender of the people in this age group (15-64).

We investigated the relationship between "Sex" and the other variables under investigation with the use of chi-square test $(\chi 2)$. In order to extract the results of the chi-square test we used the statistical software SPAD v.4.5 offered by the Faculty of Humanities of the University of the Aegean.

\section{Results}

It is observed that $69.89 \%$ of men and $70.64 \%$ of women are located in urban areas. $30.11 \%$ of men and $29.63 \%$ of women are in rural areas (Table 1).

Table 1. Area

\begin{tabular}{lllll}
\hline & Men & \multicolumn{3}{c}{ Women } \\
\hline & $\mathrm{n}$ & $\%$ & $\mathrm{n}$ & $\%$ \\
\hline Urban & 3499854 & $69.89 \%$ & 3719418 & $70.64 \%$ \\
Rural & 1507883 & $30,11 \%$ & 1545663 & $29.36 \%$ \\
Total & 5007737 & $100.00 \%$ & 5265081 & $100.00 \%$ \\
\hline
\end{tabular}

$29.83 \%$ of men, and $27.98 \%$ of women are between the ages of 15 and 24 years old. $23.32 \%$ of men, and $24.40 \%$ of 
women are between 25 and 34 years old. $20.29 \%$ of men and $20.84 \%$ of women are between 35 and 44 years old. $15.81 \%$ of men, and $15.99 \%$ of women are between 45 and 54 years old. Finally, $10.76 \%$ of men, and $10.79 \%$ of women are between 55 and 64 years old (Table 2).

Table 2. Age

\begin{tabular}{lllll}
\hline & Men & \multicolumn{3}{l}{ Women } \\
\hline & $\mathrm{n}$ & $\%$ & $\mathrm{n}$ & $\%$ \\
\hline $15-24$ & 1493602 & $29.83 \%$ & 1473101 & $27.98 \%$ \\
$25-34$ & 1168016 & $23.32 \%$ & 1284750 & $24.40 \%$ \\
$35-44$ & 1015907 & $20.29 \%$ & 1097415 & $20.84 \%$ \\
$45-54$ & 791563 & $15.81 \%$ & 841887 & $15.99 \%$ \\
$55-64$ & 538650 & $10.76 \%$ & 567928 & $10.79 \%$ \\
Total & 5007738 & $100.00 \%$ & 5265081 & $100.00 \%$ \\
\hline
\end{tabular}

It is observed that $32.75 \%$ of men and $32.90 \%$ of women are married, $3.99 \%$ of men and $8.71 \%$ of women are separated, $1.36 \%$ of men and $2.76 \%$ of women are divorced, $0.63 \%$ of men and $2.41 \%$ of women are widowed. $24.66 \%$ of men and $24.11 \%$ of women are common law and $36.61 \%$ of men and $29.11 \%$ of women are single (Table 3).

Table 3. Marital status

\begin{tabular}{lllll}
\hline & Men & \multicolumn{3}{l}{ Women } \\
\hline & $\mathrm{n}$ & $\%$ & $\mathrm{n}$ & $\%$ \\
\hline Married & 1640074 & $32.75 \%$ & 1732088 & $32.90 \%$ \\
Separated & 199789 & $3.99 \%$ & 458442 & $8.71 \%$ \\
Divorced & 67905 & $1.36 \%$ & 145240 & $2.76 \%$ \\
Widowed & 31581 & $0.63 \%$ & 127144 & $2.41 \%$ \\
Common Law & 1235001 & $24.66 \%$ & 1269332 & $24.11 \%$ \\
Single & 1833387 & $36.61 \%$ & 1532836 & $29.11 \%$ \\
Total & 5007737 & $100.00 \%$ & 5265082 & $100.00 \%$ \\
\hline
\end{tabular}

$29.69 \%$ of men have post - primary education and a similar percentage $(29.06 \%)$ of women have the same level of education. $26.72 \%$ of men have elementary education, instead $25.70 \%$ of women have the same level. $16.63 \%$ of men have higher education and $19.18 \%$ of women have this level (Table 4).

Table 4. Educational Attainment

\begin{tabular}{lllll}
\hline & Men & \multicolumn{3}{l}{ Women } \\
\hline None & $\mathrm{n}$ & $\%$ & $\mathrm{n}$ & $\%$ \\
Literacy Center & 90867 & $1.81 \%$ & 155916 & $2.96 \%$ \\
Elementary education & 10799 & $0.22 \%$ & 21723 & $0.41 \%$ \\
Basic Education & 1338184 & $26.72 \%$ & 1353184 & $25.70 \%$ \\
Post-primary education & 436996 & $8.73 \%$ & 393904 & $7.48 \%$ \\
Secondary school & 1486881 & $29.69 \%$ & 1530234 & $29.06 \%$ \\
Higher education & 691585 & $13.81 \%$ & 670290 & $12.73 \%$ \\
Further education (undergraduate) & 68317 & $1.36 \%$ & 79084 & $1.50 \%$ \\
Post-graduated & 832544 & $16.63 \%$ & 1009640 & $19.18 \%$ \\
Total & 51563 & $1.03 \%$ & 51106 & $0.97 \%$ \\
\hline
\end{tabular}

In terms of language, the vast majority of men $(92.18 \%)$ and women $(91.94 \%)$ speak only Spanish. $0.07 \%$ of men and $0.13 \%$ of women speak only native indigenous language. $5.53 \%$ of men and $5.70 \%$ of women speak native indigenous language and Spanish, and $2.02 \%$ of men and $2.01 \%$ of women speak Spanish and a foreign language (Table 5). 
Table 5. Language Spoken

\begin{tabular}{lllll}
\hline & Men & \multicolumn{3}{l}{ Women } \\
\hline & $\mathrm{n}$ & $\%$ & $\mathrm{n}$ & $\%$ \\
\hline Only Indigenous language & 3404 & $0.07 \%$ & 6995 & $0.13 \%$ \\
Indigenous language and Spanish & 277130 & $5.53 \%$ & 300158 & $5.70 \%$ \\
Only Spanish & 4616109 & $92.18 \%$ & 4840604 & $91.94 \%$ \\
Spanish and foreign language & 101329 & $2.02 \%$ & 105983 & $2.01 \%$ \\
Indigenous and foreign language & 842 & $0.02 \%$ & 638 & $0.01 \%$ \\
Foreign language & 2313 & $0.05 \%$ & 3728 & $0.07 \%$ \\
Do not speak & 6610 & $0.13 \%$ & 6975 & $0.13 \%$ \\
Total & 5007737 & $100.00 \%$ & 5265081 & $100.00 \%$ \\
\hline
\end{tabular}

Regarding racial groups, $7.01 \%$ of men and $7.14 \%$ of women consider themselves as indigenous. A $1.32 \%$ of men and $1.29 \%$ of women consider themselves as Afro-Ecuadorian. However, $81.22 \%$ of men and $81.76 \%$ of women consider themselves as a Mestizo (Table 6).

Table 6. How the subjects identify themselves

\begin{tabular}{lllll}
\hline & Men & \multicolumn{3}{l}{ Women } \\
\hline & $\mathrm{n}$ & $\%$ & $\mathrm{n}$ & $\%$ \\
\hline Indigenous & 351278 & $7.01 \%$ & 375937 & $7,14 \%$ \\
Afro-Ecuadorian & 66347 & $1.32 \%$ & 67748 & $1.29 \%$ \\
Black & 100001 & $2.00 \%$ & 103981 & $1.97 \%$ \\
Mulatto & 57943 & $1.16 \%$ & 67303 & $1.28 \%$ \\
Montubio & 274306 & $5.48 \%$ & 245965 & $4.67 \%$ \\
Mestizo & 4067150 & $81.22 \%$ & 4304808 & $81.76 \%$ \\
White & 89117 & $1.78 \%$ & 98313 & $1.87 \%$ \\
Other & 1594 & $0.03 \%$ & 1026 & $0.02 \%$ \\
Total & 5007736 & $100.00 \%$ & 5265081 & $100.00 \%$ \\
\hline
\end{tabular}

$65.13 \%$ of men and $64.73 \%$ of women state that they were born in the same city of the survey, while $33.70 \%$ of men and $33.96 \%$ of women say that they were born in another place of the country. $1.18 \%$ of men and $1.31 \%$ of women state that they were born in another country (Table 7).

Table 7. Place of birth

\begin{tabular}{lllll}
\hline & Men & \multicolumn{3}{l}{ Women } \\
\hline & $\mathrm{n}$ & $\%$ & $\mathrm{n}$ & $\%$ \\
\hline In this city & 3261308 & $65.13 \%$ & 3408083 & $64.73 \%$ \\
Inside the country & 1687584 & $33.70 \%$ & 1788088 & $33.96 \%$ \\
In a foreign country & 58845 & $1.18 \%$ & 68911 & $1.31 \%$ \\
Total & 5007737 & $100.00 \%$ & 5265082 & $100.00 \%$ \\
\hline
\end{tabular}

$47.62 \%$ of men state that the main reason to stay in the city is his job; the second reason (35.23\%) is that they came with the family and the third one is studies $(4.51 \%)$. While for women the main reason to stay in the city $(54.50 \%)$ is that they came with their family. The second reason $(10.95 \%)$ is because of marriage and $(5.39 \%)$ is due to studies (Table 8).

$76.43 \%$ of men in inactive conditions are students, $9.20 \%$ of them are disabled, $8.54 \%$ face other conditions. Finally, $4.06 \%$ has retired pension. With regard to women, $63.84 \%$ of them are in inactive conditions (housewives). $28.74 \%$ are students and $2.81 \%$ are disabled (Table 9 ). 
Table 8 . Reasons to change residence

\begin{tabular}{lllll}
\hline & Men & \multicolumn{3}{l}{ Women } \\
\hline Job & $\mathrm{n}$ & $\%$ & $\mathrm{n}$ & $\%$ \\
To improve income & 747999 & $47.62 \%$ & 368902 & $21.51 \%$ \\
Marriage & 59965 & $3.82 \%$ & 58073 & $3.39 \%$ \\
Studies & 53016 & $3.37 \%$ & 187828 & $10.95 \%$ \\
Health or disease & 70847 & $4.51 \%$ & 92445 & $5.39 \%$ \\
Bought or gave land or house & 11012 & $0.70 \%$ & 12793 & $0.75 \%$ \\
Came with the family & 42458 & $2.70 \%$ & 24741 & $1.44 \%$ \\
Other & 553369 & $35.23 \%$ & 934461 & $54.50 \%$ \\
Total & 32198 & $2.05 \%$ & 35453 & $2.07 \%$ \\
\hline
\end{tabular}

Table 9. Status of Inactivity

\begin{tabular}{lllll}
\hline & \multicolumn{3}{l}{ Men } & \multicolumn{3}{l}{ Women } \\
\cline { 2 - 5 } & $\mathrm{n}$ & $\%$ & $\mathrm{n}$ & $\%$ \\
\cline { 2 - 5 } Rentier & 9494 & $1.12 \%$ & 25088 & $1.06 \%$ \\
Retired Pension & 34502 & $4.06 \%$ & 38226 & $1.61 \%$ \\
Student & 649408 & $76.43 \%$ & 681239 & $28.74 \%$ \\
Housewife & 5603 & $0.66 \%$ & 1513188 & $63.84 \%$ \\
Disabled & 78184 & $9.20 \%$ & 66559 & $2.81 \%$ \\
Other & 72524 & $8.54 \%$ & 45937 & $1.94 \%$ \\
Total & 849715 & $100.00 \%$ & 2370237 & $100.00 \%$ \\
\hline
\end{tabular}

In the labor satisfaction variable, $71.93 \%$ of men and $76.73 \%$ of women are satisfied with their jobs, while $16.47 \%$ of men and $14.04 \%$ of women are not satisfied with it. $8.96 \%$ of men are not happy but satisfied and $6.90 \%$ of women have the same feeling. $2.46 \%$ of man and $2.24 \%$ of women are totally in discontent (Table 10).

Table 10. The level of happiness at work

\begin{tabular}{lllll}
\hline & Men & \multicolumn{3}{c}{ Women } \\
\hline & $\mathrm{n}$ & $\%$ & $\mathrm{n}$ & $\%$ \\
\hline Happy & 2869483 & $71.93 \%$ & 2080552 & $76.73 \%$ \\
Not very Happy & 656863 & $16.47 \%$ & 380614 & $14.04 \%$ \\
Unhappy but conformant & 357488 & $8.96 \%$ & 187055 & $6.90 \%$ \\
Completely unhappy & 98023 & $2.46 \%$ & 60863 & $2.24 \%$ \\
NA & 7430 & $0.19 \%$ & 2311 & $0.09 \%$ \\
Total & 3989287 & $100.00 \%$ & 2711395 & $100.00 \%$ \\
\hline
\end{tabular}

$8.83 \%$ of women surveyed are pregnant or in lactation period and $91.17 \%$ are not (Table 11 ).

Table 11. Pregnant or in the lactation period

\begin{tabular}{lll}
\hline & $\mathrm{n}$ & $\%$ \\
\hline Yes & 378770 & $8.83 \%$ \\
No & 3912462 & $91.17 \%$ \\
Total & 4291232 & $100.00 \%$ \\
\hline
\end{tabular}

$78.45 \%$ of men have an activated cellphone, while only $73.27 \%$ of women have it, the difference is $5.18 \% .40 .28 \%$ of men and $38.6 \%$ of women have a smartphone (table 12 and 13 ). 
Table 12. Have an activated cellular phone

\begin{tabular}{lllll}
\hline & Men & \multicolumn{3}{l}{ Women } \\
\cline { 2 - 5 } & $\mathrm{n}$ & $\%$ & $\mathrm{n}$ & $\%$ \\
\hline Yes & 3737108 & $78.45 \%$ & 3757094 & $73.27 \%$ \\
No & 1026481 & $21.55 \%$ & 1370612 & $26.73 \%$ \\
Total & 4763589 & $100.00 \%$ & 5127706 & $100.00 \%$ \\
\hline
\end{tabular}

Table 13. Have a smartphone

\begin{tabular}{lllll}
\hline & Men & \multicolumn{3}{c}{ Women } \\
\hline & $\mathrm{n}$ & $\%$ & $\mathrm{n}$ & $\%$ \\
\hline Yes & 1505160 & $40.28 \%$ & 1441216 & $38.36 \%$ \\
No & 2231948 & $59.72 \%$ & 2315878 & $61.64 \%$ \\
Total & 3737108 & $100.00 \%$ & 3757094 & $100.00 \%$ \\
\hline
\end{tabular}

With regard to computer use, $53.98 \%$ of men and $51.18 \%$ of women used a computer in the last year (Table 14), while $55.7 \%$ of men and $53.22 \%$ of women used internet at the same period (Table 15 ).

Table 14. Have used a computer in the past 12 months

\begin{tabular}{lllll}
\hline & Men & \multicolumn{3}{l}{ Women } \\
\cline { 2 - 5 } & $\mathrm{n}$ & $\%$ & $\mathrm{n}$ & $\%$ \\
\cline { 2 - 5 } Yes & 2571212 & $53.98 \%$ & 2624366 & $51.18 \%$ \\
No & 2192377 & $46.02 \%$ & 2503340 & $48.82 \%$ \\
Total & 4763589 & $100.00 \%$ & 5127706 & $100.00 \%$ \\
\hline
\end{tabular}

Table 15. Have used the Internet in the past 12 months

\begin{tabular}{lllll}
\hline & Men & \multicolumn{3}{c}{ Women } \\
\cline { 2 - 5 } & $\mathrm{n}$ & $\%$ & $\mathrm{n}$ & $\%$ \\
\hline Yes & 2653184 & $55.70 \%$ & 2729090 & $53.22 \%$ \\
No & 2110404 & $44.30 \%$ & 2398615 & $46.78 \%$ \\
Total & 4763588 & $100.00 \%$ & 5127705 & $100.00 \%$ \\
\hline
\end{tabular}

Table 16. Have you been in a training course in the las 12 months

\begin{tabular}{lllll}
\hline & \multicolumn{3}{l}{ Men } & \multicolumn{3}{l}{ Women } \\
\cline { 2 - 5 } & $\mathrm{n}$ & $\%$ & $\mathrm{n}$ & $\%$ \\
\cline { 2 - 5 } Yes & 568429 & $11.94 \%$ & 437475 & $8.54 \%$ \\
No & 4191453 & $88.06 \%$ & 4685506 & $91.46 \%$ \\
Total & 4759882 & $100.00 \%$ & 5122981 & $100.00 \%$ \\
\hline
\end{tabular}

Both genders trained in Ecuador show a low rate index; however, while $11.94 \%$ of men have attended a training course over the last year, only $8.54 \%$ of women attended it. $91.46 \%$ of women have not attended any particular training course in the last year (Table 16).

There are four regions in Ecuador, Coastal Region, Mountain Region, the Amazon and the Galapagos Islands. $44.04 \%$ of men belongs to the Mountain Region, $50.84 \%$ belongs to the Coastal Region, $4.93 \%$ belong to the Amazon Region and only $0.19 \%$ belongs to the Galapagos Islands. Regarding women, $46.14 \%$ belongs to the Mountain Region, $49.04 \%$ to the Coastal Region, $4.64 \%$ to the Amazon Region and $0.18 \%$ to the Galapagos Islands (Table 17). 
Table 17. Native Region

\begin{tabular}{lllll}
\hline & Men & \multicolumn{3}{l}{ Women } \\
\cline { 2 - 5 } & $\mathrm{n}$ & $\%$ & $\mathrm{n}$ & $\%$ \\
\hline Mountain Region & 2205312 & $44.04 \%$ & 2429400 & $46.14 \%$ \\
Coastal Region & 2545845 & $50.84 \%$ & 2581783 & $49.04 \%$ \\
The Amazon Region & 246887 & $4.93 \%$ & 244487 & $4.64 \%$ \\
Insular Region & 9692 & $0.19 \%$ & 9412 & $0.18 \%$ \\
Total & 5007736 & $100.00 \%$ & 5265082 & $100 \%$ \\
\hline
\end{tabular}

The survey show that $81.72 \%$ of men are not in poverty and $18.28 \%$ of men consider themselves in poverty, while $79.59 \%$ of women are not in poverty and $20.41 \%$ consider themselves in poverty (Table 18 ). In extreme poverty case, $6.36 \%$ of men and $7.26 \%$ of women consider themselves indigent (Table 19).

Table 18. Income poverty

\begin{tabular}{lllll}
\hline & Men & \multicolumn{3}{l}{ Women } \\
\cline { 2 - 5 } & $\mathrm{n}$ & $\%$ & $\mathrm{n}$ & $\%$ \\
\hline Not poor & 4042929 & $81.72 \%$ & 4140856 & $79.59 \%$ \\
Poor & 904188 & $18.28 \%$ & 1061761 & $20.41 \%$ \\
Total & 4947117 & $100.00 \%$ & 5202617 & $100.00 \%$ \\
\hline
\end{tabular}

Table 19. Extreme poverty

\begin{tabular}{lllll}
\hline & Men & \multicolumn{3}{c}{ Women } \\
\cline { 2 - 5 } & $\mathrm{n}$ & $\%$ & $\mathrm{n}$ & $\%$ \\
\hline Not indigent & 4632284 & $93.64 \%$ & 4824981 & $92.74 \%$ \\
Indigent & 314833 & $6.36 \%$ & 377636 & $7.26 \%$ \\
Total & 4947117 & $100.00 \%$ & 5202617 & $100.00 \%$ \\
\hline
\end{tabular}

The activity conditions are: $45.76 \%$ of men have suitable employment, $18.22 \%$ have inappropriate employment, and $16.97 \%$ belongs to economically inactive population. While in women $45.02 \%$ belongs to economically inactive population, $21.07 \%$ have a suitable employment and $15.36 \%$ have inappropriate employment. Also in women $6.78 \%$ have an unpaid job, while $3.34 \%$ of men have this activity condition (Table 20).

Table 20. Activity status

\begin{tabular}{lllll}
\hline & Men & \multicolumn{3}{l}{ Women } \\
\cline { 2 - 5 } & $\mathrm{n}$ & $\%$ & $\mathrm{~N}$ & $\%$ \\
\hline Suitable job & 2291358 & $45.76 \%$ & 1109334 & $21.07 \%$ \\
Underemployment due to insufficient work & 440979 & $8.81 \%$ & 370654 & $7.04 \%$ \\
Underemployment due to insufficient income & 148038 & $2.96 \%$ & 50143 & $0.95 \%$ \\
Other unsuitable employment & 912321 & $18.22 \%$ & 808742 & $15.36 \%$ \\
Unpaid employment & 167433 & $3.34 \%$ & 357178 & $6.78 \%$ \\
Unclassified employment & 29157 & $0.58 \%$ & 15343 & $0.29 \%$ \\
Open unemployment & 138474 & $2.77 \%$ & 133546 & $2.54 \%$ \\
Hidden unemployment & 30261 & $0.60 \%$ & 49902 & $0.95 \%$ \\
Economically inactive population & 849715 & $16.97 \%$ & 2370238 & $45.02 \%$ \\
Total & 5007736 & $100.00 \%$ & 5265080 & $100.00 \%$ \\
\hline
\end{tabular}

$25.91 \%$ of men and $19.61 \%$ of women are dedicated to agriculture, farming, livestock and fishing. $15.49 \%$ of men and $23.53 \%$ of women are dedicated to business and vehicle fixing. $12.31 \%$ of men is dedicated to house building activities. $11.79 \%$ of men is dedicated to the manufacturing industry and although women also do it, their value is $9.42 \% .9 .77 \%$ of men is dedicated to storage and transport. Other activity branches with important value to women 
are: lodging and cooking $(10.18 \%)$, teaching $(7.79 \%)$, and activities of domestic services $(6.50 \%)$ (Table 21$)$.

Table 21. Type of Activity

\begin{tabular}{lllll}
\hline & Hombres & \multicolumn{3}{l}{ Mujeres } \\
\hline & $\mathrm{n}$ & $\%$ & $\mathrm{n}$ & $\%$ \\
\hline Agriculture, livestock farming and fishing & 1033477 & $25.91 \%$ & 531795 & $19.61 \%$ \\
Mining and quarrying & 45544 & $1.14 \%$ & 3068 & $0.11 \%$ \\
Manufacturing & 470187 & $11.79 \%$ & 255391 & $9.42 \%$ \\
Electricity, gas, air conditioning supplies & 20768 & $0.52 \%$ & 3467 & $0.13 \%$ \\
Water distribution, sewage & 16192 & $0.41 \%$ & 4978 & $0.18 \%$ \\
Construction & 491099 & $12.31 \%$ & 20325 & $0.75 \%$ \\
Commerce and vehicle repair & 618004 & $15.49 \%$ & 638049 & $23.53 \%$ \\
Transport and storage & 389650 & $9.77 \%$ & 33545 & $1.24 \%$ \\
Accomodation and food storage & 141400 & $3.54 \%$ & 275997 & $10.18 \%$ \\
Information and communication & 49276 & $1.24 \%$ & 34735 & $1.28 \%$ \\
Financial and insurance activities & 27013 & $0.68 \%$ & 31240 & $1.15 \%$ \\
Real estate activities & 4874 & $0.12 \%$ & 4004 & $0.15 \%$ \\
Professional, scientific and technical activities & 67372 & $1.69 \%$ & 50504 & $1.86 \%$ \\
Administrative services and support & 125953 & $3.16 \%$ & 64773 & $2.39 \%$ \\
Public administration, defense and social security & 215820 & $5.41 \%$ & 94488 & $3.48 \%$ \\
Teaching & 117402 & $2.94 \%$ & 211186 & $7.79 \%$ \\
Social services and health & 46708 & $1.17 \%$ & 126168 & $4.65 \%$ \\
Arts, entertainment and recreation & 27954 & $0.70 \%$ & 14593 & $0.54 \%$ \\
Other service activities & 69513 & $1.74 \%$ & 136749 & $5.04 \%$ \\
Activities of domestic service & 10274 & $0.26 \%$ & 176341 & $6.50 \%$ \\
Activities of extraterritorial organizations & 807 & $0.02 \%$ & 0 & $0.00 \%$ \\
Total & 3989287 & $100.00 \%$ & 2711396 & $100.00 \%$ \\
\hline
\end{tabular}

\section{The Chi-Square Test}

The correlation between the variable "Sex" and the other variables under investigation was studied with the use of chi-square test $(\chi 2)$. The correlations in which the Valor Test (V.Test) is greater than or equal to two are statistically interesting. The larger than two the V.Test, the greater the correlation between two variables (Morineau, 1984).

The results of chi-square test showed that there is a significant correlation between "Sex" and the majority of the variables under investigation:

Sex * Area: $\chi 2=20.23 / 1$ degree of freedom $/$ V.Test $=4.35$

Sex * Age: $\chi 2=51.78 / 4$ degrees of freedom $/$ V.Test $=6.30$

Sex * Marital status: $\chi 2=1158.47 / 5$ degrees of freedom $/$ V.Test $=99.99$

Sex * Educational Attainment: $\chi 2=334.18 / 8$ degrees of freedom $/$ V.Test $=99.99$

Sex * Language spoken: $\chi 2=9.48 / 6$ degrees of freedom $/$ V.Test $=1.04$

Sex * How the subjects identify themselves: $\chi 2=17.94 / 7$ degrees of freedom $/$ V.Test $=2.25$

Sex * Place of birth: $\chi 2=3.37 / 2$ degrees of freedom $/$ V.TEST $=0.90$

Sex * Reasons to change residence: $\chi 2=2032.96 / 7$ degrees of freedom $/$ V.Test $=99.99$

Sex $*$ Status of inactivity: $\chi 2=6266.36 / 5$ degrees of freedom $/$ V.Test $=99.99$

Sex * Level of happiness at work: $\chi 2=126.44 / 3$ degrees of freedom $/$ V.Test $=10.56$

Sex * Have an activated cellular phone: $\chi 2=433.01 / 2$ degrees of freedom $/$ V.Test $=99.99$

Sex * Have a smartphone: $\chi 2=9.44 / 1$ degree of freedom $/$ V.Test $=2.86$

Sex * Have used a computer in the past 12 months: $\chi 2=62.55 / 1$ degree of freedom $/$ V.Test $=7.82$

Sex * Have used a computer in the past 12 months: $\chi 2=60.26 / 1$ degree of freedom $/$ V.Test $=7.67$

Sex * Have you been in a training course in the las 12 months: $\chi 2=361.03 / 2$ degrees of freedom $/$ V.Test $=99.99$ 
Sex $*$ Native Region: $\chi 2=49.27 / 3$ degrees of freedom $/$ V.Test $=6.34$

Sex * Type of Activity: $\chi^{2}=7165.96 / 20$ degrees of freedom $/$ V.Test $=83.87$

Sex * Income poverty: $\chi 2=15.78 / 1$ degree of freedom $/$ V.Test $=3.80$

Sex * Extreme poverty: $\chi 2=8.35 / 1$ degree of freedom $/$ V.Test $=2.66$

Sex * Activity status: $\chi 2=7573.75 / 8$ degrees of freedom $/$ V.Test $=99.99$

\section{Conclusion}

Even though the efforts seeking a fairer global society concerning equitable development between men and women, and the results achieved, gender parity is still present. The present research work determines the economic, educational, social and demographic profile of Ecuadorian women and men between 15 and 64 years old aiming to observe the characteristics and differences that exist between them. It also seeks to describe the concordance with the national reports related to this topic and describes the relationship between the variables under analysis and their characteristics by gender to conclude about it. In the framework of this study, a descriptive analysis was realized, and also a chi-square test that confirmed the results of the descriptive analysis (Sarmiento et al, 2016).

In the urban area is the main place of residence regardless the gender. The vast majority of the population consider themselves as mestizos. However, there are two minority groups who consider themselves as indigenous and montubios. In reference to the internal mobility, the percentage between men and women is similar. However, employment is the primary reason of migration for men. In contrast, the primary reason for women is the family.

The main language of the population is Spanish. There is a minority of the population who speaks Spanish and an indigenous language and Spanish and a foreign language. The level of schooling is also similar between male and female in primary and secondary school, but women are up in the indicators related to higher education with respect to men.

Regarding activity conditions, there are big differences in terms of gender. Less than half of men believe that they have an adequate job, while the fifth part of women consider they have an adequate job. Among economically inactive male, they represent a fifth of the total male population. On the other hand, women in this condition, represent almost a half of the total of this group. Finally, in the indicator of unpaid job, women duplicate the percentage of men.

Regarding the economically active population, the vast majority of men is dedicated to farming, hunting, forestry, and fishing, followed by sale and vehicle fixing, building industry, and transportation and warehousing. The main branches of activity for women are: repair and sale of vehicles, agriculture, hunting, forestry, and fishing, accommodation activities and food service, teaching and domestic services correspondingly. The majority of inactive men are students, while in the case of women under the same condition, more than a half are housekeepers.

In relation to access and use of technology more than a half of the population have used a computer over the last twelve months. On the other hand, three quarters of the population own an activated cellphone, but less than a half own a smartphone.

Overall, gender differences in variables related to labor, unpaid work, use of technology, mobility which are observed and might represent an indicator of the gender parity remain (INEC, 2015).

\section{Acknowledgments}

Immeasurable appreciation and deepest gratitude to Universidad Politécnica Salesiana and Universidad Nacional de Educación UNAE that supported our investigation. We would also like to express our sincere gratitude to the Faculty of Humanities of the University of the Aegean that offered us the statistical software SPAD v.4.5 we used in our research.

\section{References}

Altonji, J. G., \& Blank, R. M. (1999). Race and Gender in the labor market. En Handbook of Labor Economics, 3, 3144-3251. ElsevierScience.

Bambra, C. (2010). Yesterday once more? Unemployment and health in the 21st century. Journal of Epidemiology \& Communitu Health, 213-215.

Bertrand, M. (2010). New Perspectives on Gender. En Handbook of Labor Economics, 1546-1584. Elsevier Ltd.

Blau, F. D., \& Lawrence, K. M. (2000). Gender Differences in Pay. The Journal of Economic Perspectives, 75-99. 
Carnoy, M. (2002). Sustaining the New Economy. Work, Family and Community in the information age. Cambridge: Harvard University Press.

Castaño, C., Iglesias, C., Mañas, E., \& Sanchez-Herrero, M. (1999). Diferencia o discriminación. La situación de las mujeres españolas en el mercado de trabajo y el impacto. Madrid, España: Colección Estudios.

Castellano, J., Stefos, E., \& Williams Goodrich, L. G. (2017). The Educational and Social Profile of the Indigenous People of Ecuador: A Multidimensional Analysis. Review of European Studies, 9(1), 137-147. https://doi.org/10.5539/res.v9n1p137

Comisión Economica para América Latina y el Caribe - CEPAL (2013). Panorama Social de América Latina. Santiago de Chile: CEPAL.

Escribà Agüir, V., \& Fons Martinez, J. (2014). Crisis económica y condiciones de empleo: diferencias de género y. Gaceta Sanitaria, 37-43.

Formichella, M., \& London, S. (2012). Empleabilidad, educación y equidad social. Revista de Estudios Sociales, 80-91.

Instituto Nacional de Estadísticas y Censos - INEC (2015). Encuesta Nacional de Empleo, Desempleo y Subempleo ENEMDU. Quito.

Kleven, H., \& Landais, C. (2017). Gender Inequality and Economic Development: Fertitily, Education and Norms. ECONOMICA, 84. https://doi.org/10.1111/ecca.12230

Midgley, J. (2014). Desarrollo Social: Teoría y Práctica. Madrid, España: FGUPM.

Morineau, A. (1984). Note sur la Caracterisation Statistique d'une Classe et les Valeurs tests. Bulletin Technique du Centre de Statistique et d'Informatique Appliquées, 2(1-2), p.20-27.

Naciones Unidas (2000). Declaración del Milenio.13 septiembre de 2000. Dist. General. Retrieved from http://www.cinu.mx/minisitio/ODM8/docs/Declaraci\%C3\%B3n\%20del\%20Milenio.pdf

Naciones Unidas (2015). Objetivos de Desarrollo del Milenio Informe 2015. Nueva York. Retrieved from http://www.un.org/es/millenniumgoals/pdf/2015/mdg-report-2015_spanish.pdf

Naciones Unidas (2017). Objetivos de Desarrollo del Milenio y más alla del 2015. Retrieved from http://www.un.org/es/millenniumgoals/

Organisation for Economic Co-operation and Development OECD (2007). ICTs and Gender. OECD. Retrieved from http://www.oecd.org/sti/ieconomy/38332121.pdf

Organización Mundial del Comercio (1998). Informe de la Decimosexta Conferencia Internacional de Estadísticos del Trabajo. Ginebra. 1998. Retrieved from http://ilo.org/wcmsp5/groups/public/---dgreports/-stat/documents/meetingdocument/wcms_087601.pdf

Organización Mundial del Comercio (1998).Informe de la Decimosexta Conferencia Internacional de Estadísticos del Trabajo. Ginebra. 1998. Retrieved from http://ilo.org/wcmsp5/groups/public/---dgreports/-stat/documents/meetingdocument/wcms_087601.pdf

Rentería Pérez, E., \& Malvezzi, S. (2008). Empleabilidad, cambios y exigencias psocosociales en el trabajo, 7 , 319-334.

Saltos Chacán, M. Y., Muñoz Moreta, E. R., \& Rodríguez Mañay, L. O. (2016). Empleabilidad y Seguimiento a graduados de la Carrera de Administración de Empresas de la Universidad Central del Ecuador, año 2014, su aporte en la perspectiva para el proceso de construcción del modelo de formación universitaria. Revista Publicando, 116-144.

Sarmiento, N. M., Paredes, A. M., \& Stefos, E. (2016). Deaths by Suicide in Ecuador: A Quantitative Data Analysis. Review of European Studies, 8(1), 145-156. https://doi.org/10.5539/res.v8n1p145

Senplades, Inec, P., \& Snu (2014). Objetivos del Milenio Balance Ecuador 2014. Quito.

Suárez, \& Lantaron, B. (2014). La universidad española ante la empleabilidad de sus graduados: estrategias para su mejora. REOP, 25(2), 90-110.

Tito, M. D. (2016). Maternity Leave and the Gender Wage Gap: An Analysis of New Jersey Family Leave Insurance. FEDS Notes.

Vásquez Parra, J. C., Arredondo Tapero, F. G., \& De la Garza García, J. (2016). Brecha de género en los países miembros de la Alianza del Pacífico. Journal of Management and Economics for Iberoamerica, 32(141), 
336-345.

World Economic Forum - WEF (2016). The Global Gender Gap Report. Geneva: World Economic Forum.

\section{Copyrights}

Copyright for this article is retained by the author(s), with first publication rights granted to the journal.

This is an open-access article distributed under the terms and conditions of the Creative Commons Attribution license (http://creativecommons.org/licenses/by/4.0/). 